\title{
Isolation of functional total RNA from Argemone mexicana tissues
}

\author{
Jorge A. Rubio-Piña \\ Unidad de Bioquímica y Biología Molecular de Plantas \\ Programa de Posgrado en Ciencias y Biotecnología de Plantas \\ Centro de Investigación Científica de Yucatán \\ Calle 43 No. 130, Colonia Chuburná de Hidalgo \\ Mérida, Yucatán, México. \\ Fax: 9999813900 \\ E-mail: jrubio@cicy.mx \\ Felipe A. Vázquez-Flota* \\ Unidad de Bioquímica y Biología Molecular de Plantas \\ Centro de Investigación Científica de Yucatán \\ Calle 43 No. 130, Colonia Chuburná de Hidalgo \\ Mérida 97200, Yucatán, México \\ Tel: 9999428330 \\ Fax: 9999813900 \\ E-mail: felipe@cicy.mx
}

Financial support: National Council for Science and Technology (CONACYT), Mexico.

Keywords: Argemone mexicana, plant tissues, RNA isolation, secondary metabolites.

\begin{abstract}
Abbreviations: CTAB: hexadecyltrimethylammonium bromide DEPC: diethyl pyrocarbonate PVPP: polyvinylpolypyrrolidone RT-PCR: reverse transcription polymerase chain reaction SDS: sodium dodecyl sulfate
\end{abstract}

RNA extraction from recalcitrant plant tissues is frequently complicated by the presence of secondary metabolites, polysaccharides and polyphenols. These compounds may co precipitate with RNA, often rendering it unsuitable for either cDNA synthesis or hybridization in northern blot analyses and therefore, interfering with the gene analysis expression in such tissues. We have developed an efficient RNA extraction method from $A$. mexicana tissues. The procedure includes the use of polyvinylpolypyrrolidone (PVPP), to remove secondary metabolites, proteins and polyphenols, and a two-step precipitation with $\mathrm{LiCl}$, to eliminate polysaccharides, and thus increasing RNA yield. The quality of the resulting RNA was evaluated spectrophotometrically and by agarose gel electrophoresis. Moreover, the RNA obtained by this method, could be used directly for both RT-PCR and northern blot analysis, without any further purification.

Argemone mexicana (Papaveraceae), commonly known as prickly poppy is used in rural areas of Mexico as a medicinal plant. The occurrence of diverse alkaloids, flavonoids and fatty acids in its tissues may explain these properties (Shaukat et al. 2002; Chang et al. 2003). In fact, berberine and sanguinarine, two of the main alkaloids isolated from Argemone tisúes, display significant cytotoxic and antimicrobial properties (Villinski et al. 2003; Beuria et al. 2005). The wide range of potential medicinal uses of this plant is one of the reasons for the growing attention it is receiving. However, molecular investigations on this plant are limited.

A pre-requisite to conduct such research is obtaining high quality nucleic acids, especially RNA (Cardillo et al. 2006). However, this may be complicated in certain tissues due to RNA susceptibility to degration by RNAses. Plant tissues are characterized for a highly variable composition, and some tissues may probe especially difficult for RNA extraction (Geuna et al. 1998). Tissues of A. mexicana contain high amounts of yellow latex, which on exposure to air, rapidly turns brown due to oxidation of phenolic compounds and other secondary metabolites that interfere with any RNA extraction procedure. Furthermore, high amounts of polysaccharides often co-precipitate with RNA, thereby affecting the yield and quality of the isolated RNA (Wang et al. 2007). These substances bind to RNA and render it unsuitable for either cDNA synthesis or hybridization in northern blot analysis.

Different methods for RNA isolation have been described. In many cases; these involve both the use of detergents (CTAB, SDS) and hot phenol, or density gradient

*Corresponding author 


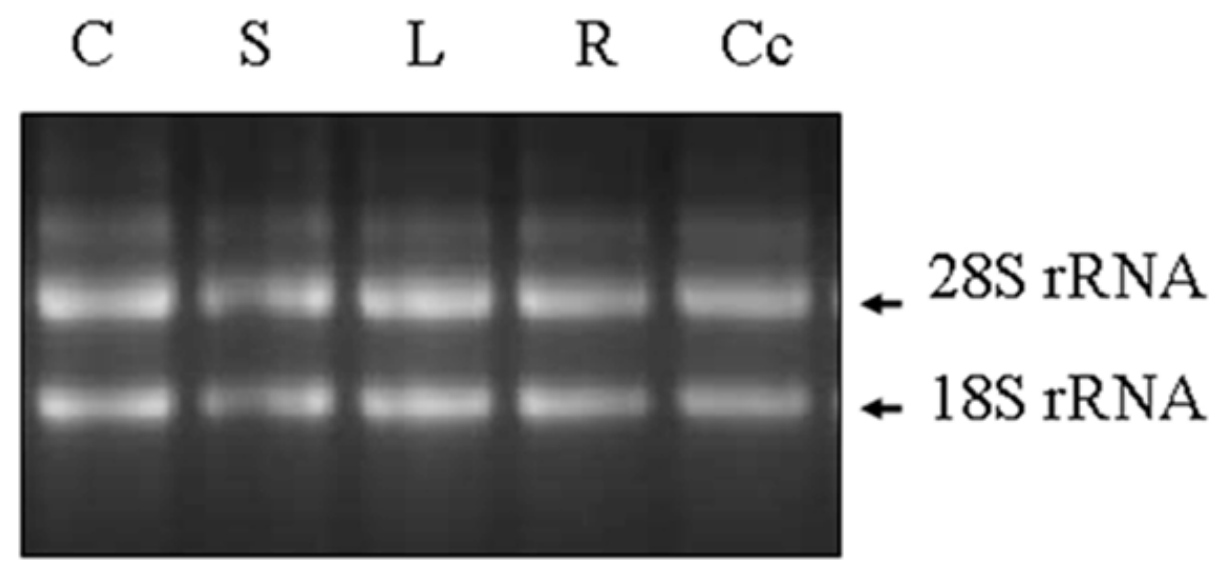

Figure 1. Electrophoretic analysis of RNA isolated from Argemone mexicana tissues. The arrows indicate the $28 \mathrm{~S}$ and $18 \mathrm{~S}$ units of rRNA. C: capsule, S: stem, L: leaf, R: root, Cc: cell culture. Total RNA samples were analyzed on an $1.5 \%$ agarose gel stained with ethidium bromide.

centrifugation (Logemann et al. 1987). However the efficiency of such methods varies depending on the composition of the employed tissues and had been inadequate in reducing polysaccharides contamination. The addition of acidic guanidinium thiocyanate or TRIzol ${ }^{\mathrm{TM}}$ (In Vitro Life Technologies, Carlsbad CA) is widely employed to inhibit RNAse activity (Chomczynski and Sacchi, 1987; Valenzuela-Avendaño et al. 2005). Organic solvents like phenol and chloroform are utilized to separate RNA from proteins into two different phases. The use of lithium chloride to precipitate RNA at certain concentrations is an effective approach for selective precipitation. However, standard procedures that make use of these reagents seldomly results in RNA with enough integrity or purity when applied to tissues with high contents of latex and secondary metabolites, such as those of $A$. mexicana. Furthermore, these procedures are frequently modified to suit specific tissues and conditions. Here, we present a reproducible method for the isolation of total RNA from different tissues of A. mexicana. The yield and quality of the RNA so obtained were consistently high, as confirmed both by spectrophotometric analysis and separation on agarose gel, and was suitable for RT-PCR.

\section{MATERIALS AND METHODS}

\section{Plant material}

Plants of A. mexicana were collected from wild populations, wrapped in polyethylene bags and kept in ice upon transfer to the laboratory. On arrival, plants were thoroughly washed with cold tap water, dissected into leaves, stems, roots and capsules, and then stored at $-80^{\circ} \mathrm{C}$ until RNA extraction.

\section{Solutions required}

- Extraction buffer: 38\% phenol saturated buffer $(\mathrm{v} / \mathrm{v}), \quad 0.8 \mathrm{M}$ guanidine thiocyanate, $0.4 \mathrm{M}$ ammonium thiocyanate, $0.1 \mathrm{M}$ sodium acetate $(\mathrm{pH}$ 5), $5 \%$ glycerol, $0.1 \%$ phenol red.

- $\quad$ Chloroform: isoamylic alcohol (24:1; v/v).

- $\quad 3 \mathrm{M}$ and $8 \mathrm{M} \mathrm{LiCl}$ solutions.

- 3 M sodium acetate ( $\mathrm{pH}$ 5.2).

- $70 \%, 100 \%$ ethanol.

- Polyvinylpolypyrrolidone (PVPP).

- Diethyl pyrocarbonate (DEPC) -treated water.

All solutions were prepared with DEPC- treated water.

\section{RNA extraction protocol}

- Transfer $1 \mathrm{~g}$ of frozen tissue to a mortar containing liquid nitrogen and $250 \mathrm{mg}$ PVPP, pulverize the tissue using a pestle until a fine powder is obtained.

- $\quad$ Add $5 \mathrm{ml}$ extraction buffer and homogenize with cold pestle until tissue has thawed. Transfer samples to sterile centrifuge tubes and incubate at room temperature for $10 \mathrm{~min}$.

- Remove insoluble material from the homogenate by centrifugation at $14,000 \mathrm{~g}$ for $10 \mathrm{~min}$ at room temperature.

- Transfer the resulting supernatant to new sterile tubes and add $1 \mathrm{ml}$ of a mixture chloroform: isoamylic alcohol (24:1).

- Shake the tube vigorously with a vortex for $15 \mathrm{sec}$, and incubate at room temperature for $2 \mathrm{~min}$. After 
further shaking, separate the phases by centrifuging the tubes at $14,000 \mathrm{~g}$ for $10 \mathrm{~min}$ at $4^{\circ} \mathrm{C}$.

- Transfer the aqueous phase to a new tube, and repeat the chloroform: isoamylic alcohol extraction.

- Transfer the aqueous phase to a new tube, and mix with 0.625 volumes of $8 \mathrm{M} \mathrm{LiCl}$ and incubate at $4^{\circ} \mathrm{C}$ for 3 hrs (if RNA yield is low, incubate overnight).

- Separate RNA precipitated total RNA by centrifuging at $17,000 \mathrm{~g}$ for $30 \mathrm{~min}$ at $4^{\circ} \mathrm{C}$. Eliminate the supernatant, then carefully wash the pellet, first with $3 \mathrm{ml}$ of $3 \mathrm{M} \mathrm{LiCl}$ and then, with 1 $\mathrm{ml}$ of $70 \%$ ethanol. Centrifuge samples at $17,000 \mathrm{~g}$ at $4^{\circ} \mathrm{C}$ for $10 \mathrm{~min}$.

- Discard the supernatant and dry up the pellet at room temperature. The pellet is resuspended in $300 \mu \mathrm{l}$ DEPC-water.

- $\quad$ RNA purified by precipitation once 0.1 volumes of $3 \mathrm{M}$ sodium acetate and 2 volumes of $100 \%$ ethanol are added and incubated at $-80^{\circ} \mathrm{C}$ for $1 \mathrm{hr}$.

- Centrifuge samples at $17,000 \mathrm{~g}$ at $4^{\circ} \mathrm{C}$ for $20 \mathrm{~min}$. Eliminate supernatant and then wash the pellet twice with $1 \mathrm{ml} 70 \%$ ethanol at $-20^{\circ} \mathrm{C}$.

- Dry the pellet at room temperature and suspend in 50 - 100 $\mu$ L DEPC- water.

(If RNA is to be used for PCR methods, perform a DNAse I treatment)

\section{Estimation of RNA quality}

The recovered RNA was quantified by OD (Lewinsohn et al. 1994), by the standard procedure. Contamination due to phenol/carbohydrates or proteins was determined by recording the OD ratios; $\mathrm{A}_{260} / \mathrm{A}_{230}$ and $\mathrm{A}_{260} / \mathrm{A}_{280}$, respectively. In order to verify RNA integrity, extracts were subjected to $1 \%$ agarose electrophoresis. Gels were stained with ethidium bromide, and visualized under UV light.

\section{Reverse transcription PCR}

Single-stranded cDNA was prepared from $2.5 \mu \mathrm{g}$ total RNA using AMV reverse transcriptase and oligo (dT), following the manufacturer's instructions (Invitrogen). The synthesized cDNA was used for PCR in order to estimate the expression level of actin gene. Actin-specific primers were used $\mathrm{F}$ (5'CACIACTACTGCTAAACGGGAAA3) and $\mathrm{R}$ (5'ACATCTGCTGGAAGGTGCTG3'). PCR sequence was as follows: DNA denaturing at $94^{\circ} \mathrm{C}$ for 3 min, followed by 35 cycles of $1 \mathrm{~min}$ at $94^{\circ} \mathrm{C}$ for DNA denaturing, $1 \mathrm{~min}$ at $55^{\circ} \mathrm{C}$ for primer annealing, and $1 \mathrm{~min}$ at $72^{\circ} \mathrm{C}$ for extension. The program was terminated with a 10 min extension at $72^{\circ} \mathrm{C}$. The amplified products were separated on a $1.5 \%$ agarose gel and visualized after ethidium bromide staining.

\section{Northern blot analysis}

Samples containing $15 \mu \mathrm{g}$ total RNA were heat denatured, separated by electrophoresis in an $1.5 \%$ agarose gel containing $15 \%$ formaldehyde, and transferred by capillarity to a nylon membrane (Hybond $\mathrm{N}+$, Amersham Biosciences; Piscatay NJ) using standard procedures

Table 1. RNA yield from different tissues of $A$. mexicana, using the described extraction procedure.

\begin{tabular}{|c|c|c|c|}
\hline \multirow{2}{*}{ Tissues } & \multicolumn{2}{|c|}{ OD $^{1}$ ratios } & Total RNA $^{2}$ \\
& & $260 / 280$ & Mg FW \\
\cline { 2 - 4 } & $260 / 230$ & 1.88 & $155(36)$ \\
\hline Capsule & 2.05 & 1.94 & $123(22)$ \\
\hline Stem & 1.89 & 1.92 & $126(27)$ \\
\hline Leaf & 1.91 & 1.75 & $174(57)$ \\
\hline Root & 1.83 & 1.70 & $192(29)$ \\
\hline
\end{tabular}

${ }^{1} \mathrm{OD}$, Optical density.

${ }^{2}$ Average of three independent repetitions, with standard deviation between brackets. 
a

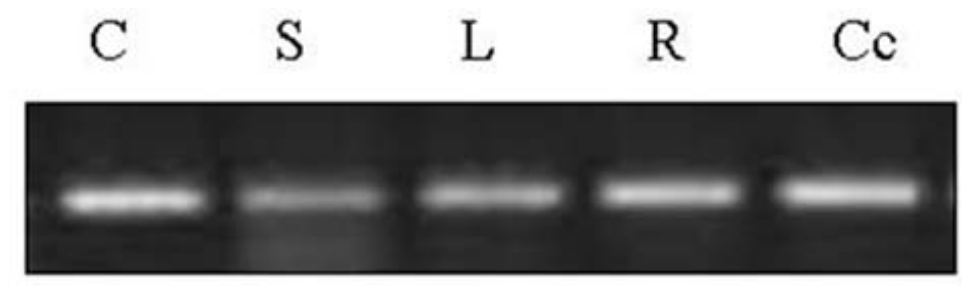

b

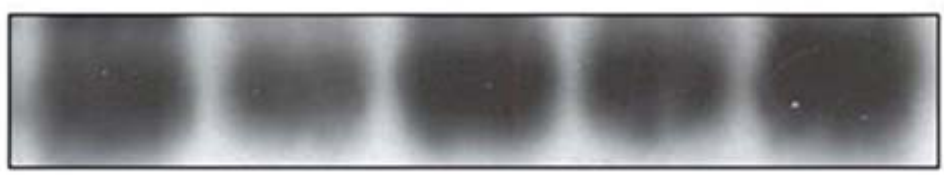

Figure 2. RT-PCR and northern blot results showing the integrity of RNA isolated. C: capsule, S: stem, L: leaf, R: root, Cc: cell culture.

(a) Agarose electrophoresis analysis of the RT-PCR assay with actin primers.

(b) Northern blot analysis of the actin gene expression using a specific DIG-labeled probes.

(Sambrook and Russel, 1989). The blot was hybridized by incubating the membrane with a DNA probe corresponding to the actin gene labelled with digoxigenin (Dig easy hyb solution; Roche Applied Science, Indianapolis IN) at $42^{\circ} \mathrm{C}$ overnight. The probe was prepared using the PCR DIG Probe Synthesis kit (Roche Applied Science), following the manufacturer's instructions. After incubation, the membrane was washed twice at room temperature in $2 \mathrm{X}$ SSC with $0.1 \%$ SDS 5 min each, and twice with $0.1 \mathrm{X}$ SSC with $0.1 \%$ SDS for $20 \mathrm{~min}$ at $65^{\circ} \mathrm{C}$ (20X SSC is $3 \mathrm{M}$ sodium chloride with $0.3 \mathrm{M}$ sodium citrate, $\mathrm{pH} 7$ ). Hybridized probes were detected using the Dig Luminescent Detection kit (Roche Applied Science) and exposing membranes to chemiluminescence sensitive films (Kodak Eastman, Rochester NY).

\section{RESULTS AND DISCUSSION}

Most A. mexicana tissues contain high amounts of latex, which besides being rich in polysaccharides, represent a source of polyphenols (Chang et al. 2003), that rapidly oxidize during grinding. This method produced a white, water soluble RNA precipitate with a significant yield (ca $150 \mu \mathrm{g}$ per gram of fresh weight, (Table 1). OD ratios (260/230 and 260/280) were 1.9 and 1.8, respectively suggesting low quantities of polysaccharides, polyphenols and proteins. RNA integrity, as observed in agarose gels (Figure 1), and yield (Table 1) were comparable to previously reported methods for tissues with high contents of polysaccharides and secondary metabolites (Chan et al. 2004; Wang et al. 2005). The absence of most polysaccharides, polyphenols and pigments in the RNA extracts from tissues of $A$. mexicana avoided interferences in two different methods employed for the detection of specific transcripts: northern blot (Figure 2a) and semiquantitative RT-PCR (Figure 2b). Moreover, the method can also be applied to A. mexicana cell cultures, which also are rich in phenols and sugars (Chang et al.
2003). This method was developed after unsuccessful attempts with other RNA isolation protocols for polysaccharide-rich tissues (Valenzuela-Avendaño et al. 2005). We noticed that the resulted after tissue grinding in the presence of buffer, rapidly turned brown perhaps, as a consequence of polysaccharide binding oxidized phenol. This darkening effect was reduced, but not completely avoided, adding $250 \mathrm{mg}$ of PVPP per gram of fresh tissue. RNA precipitation with $\mathrm{LiCl}$, followed by washing the resulting pellet with an ethanol/LiCl mixture produced not just a clear, water soluble precipitate, but also significantly increased RNA yielding.

In conclusion, we have developed a method for RNA extraction from tissues presenting high contents of both polysaccharides and polyphenols, such as those from $A$. mexicana. RNA obtained by this method can be utilized for the detection of specific RNA's, as shown in Figure 2. Although yields can be improved by precipitating RNA with $\mathrm{LiCl}$ overnight, shorter incubation periods (3 hrs) also resulted in good RNA recoveries, which allowed performing the extraction procedure of 8 samples within a 6 hrs period. It is worth noticing that, RNA yields are similar, despite the tissues being extracted: leaves, roots, stems, or capsules. This point to an important difference with respect to other reported methods, which are frequently designed for specific tissues.

\section{REFERENCES}

BEURIA, T.K.; SANTRA, M.K. and PANDA, D. Sanguinarine blocks cytokinesis in bacteria by inhibing FtsZ assembly and bundling. Biochemistry, November 2005, vol. 44, no. 50, p. 16584-16593.

CARDILLO, A.B.; GIULIETTI, A.M. and MARCONI, P.L. Analysis and sequencing of h6hmRNA, last enzyme in the tropane alkaloids pathway from anthers and hairy root 
cultures of Brugmansia candida (Solanaceae). Electronic Journal of Biotechnology, June 2006, vol. 9, no. 3.

CHAN, C.X.; TEO, S.S.; HO, C.L.; OTHMAN, R.Y. and PHANG, S.M. Optimisation of RNA extraction from Gracilaria changii (Gracilariales, Rhodophyta). Journal of Applied Phycology, August 2004, vol, 16, no. 4, p. 297301.

CHANG, Y.C.; HSIEH, P.W.; CHANG, F.R.; WU, R.R.; LIAW, C.C.; LEE, K.H. and WU, Y.C. Two new protopines argemexicaines $\mathrm{A}$ and $\mathrm{B}$ and the anti HIV alkaloid 6-acetonyldihydrochelerytrine from formosan Argemone mexicana. Planta Medica, February 2003, vol. 69, no. 6, p. 148-152.

CHOMCZYNSKI, P. and SACCHI, N. Single-step method of RNA isolation by acid guanidium thiocyanate-phenolchloroform extraction. Analytical Biochemistry, April 1987, vol. 162, no. 1, p. 156-159.

GEUNA, F.; HARTINGS, H. and SCIENZA, A. A new method for rapid extraction of high quality RNA from recalcitrant tissues of grapevine. Plant Molecular Biology Reporter, March 1998, vol. 16, no. 1, p. 61-67.

LOGEMANN, J.; SCHELL, J. and WILLMITZER, L. Improved method for the isolation of RNA from plant tissues. Analytical Biochemistry, May 1987, vol. 163, no. 1, p. 16-20.

LEWINSOHN, E.; STEELE, C.L. and CROTEAU, R. Simple isolation of functional RNA from woody stems of gymnosperms. Plant Molecular Biology Reporter, March 1994, vol. 12, no. 1, p. 20-25.

SAMBROOK, J. and RUSSEL, D. Molecular Cloning: A Laboratory Manual. $3^{\text {nd }}$ ed. Cold Spring Harbour Laboratory Press, 1989. 215 p. ISBN 0-87-969577-3.

SHAUKAT, S.S.; SIDDIQUI, I.A.; KHAN, G.H. and ZAKI, M.J. Nematicidal and allelopathic potential of Argemone mexicana, a tropical weed. Plant and Soil, August 2002, vol. 245, no. 2, p. 239-247.

VALENZUELA-AVENDAÑO, J.P.; ESTRADA-MOTA, I.A.; LIZAMA-UC, G.; SOUZA-PERERA, R.; VALENZUELA-SOTO, E.M. and ZÚÑIGA-AGUILAR, J.J. Use of a simple method to isolate intact RNA from partially hydrated Selaginella lepidophylla plants. Plant Molecular Biology Reporter, June 2005, vol. 23, no. 2, p. 199a-199g.

VILLINSKI, J.R.; DUMAS, E.R.; CHAI, H.B.; PEZZUTO, J.M.; ANGERHOFER, C.K. and GAFNER, S. Antibacterial activity and alkaloid content of Berberis thunbergii, Berberis vulgaris and Hydrastis canadensis. Pharmaceutical Biology, December 2003, vol. 41, no. 8, p. 551-557.
WANG, T.; ZHANG, N. and DU, L. Isolation of RNA of high quality and yield from Ginkgo biloba leaves. Biotechnology Letters, May 2005, vol. 27, no. 9, p. 629633.

WANG, X.; TIAN, W. and LI, Y. Development of an efficient protocol of RNA isolation from recalcitrant tree tissues. Molecular Biotechnology, January 2007, vol. 38, no. 1, p. 57-64. 